\title{
Current Mode Integrated Control Technique for Z-Source Inverter Fed Induction Motor Drives
}

\author{
Sengodan Thangaprakash ${ }^{\dagger}$ and Ammasai Krishnan* \\ ${ }^{\dagger}$ Dept. of Electrical Eng., Sri Shakthi Inst. of Eng. \& Tech., Tamil Nadu, India \\ ${ }^{*}$ Dean, K.S.R. College of Engineering, Tamil Nadu, India
}

\begin{abstract}
This paper presents a current mode integrated control technique (CM-ICT) using a modified voltage space vector modulation (MSVM) for Z-source inverter (ZSI) fed induction motor drives. MSVM provides a better DC voltage boost in the dc-link, a wide range of AC output voltage controllability and a better line harmonic profile. In a voltage mode ICT (VM-ICT), the outer voltage feedback loop alone is designed and it enforces the desired line voltage to the motor drive. An integrated control technique (ICT), with an inner current feedback loop is proposed in this paper for the purpose of line current limiting and soft operation of the drive. The current command generated by the PI controller and limiter in the outer voltage feedback loop, is compared with the actual line current, and the error is processed through the PI controller and a limiter. This limiter ensures that, the voltage control signal to the Z-source inverter is constrained to a safe level. The rise and fall of the control signal voltage are made to be gradual, so as to protect the induction motor drive and the Z-source inverter from transients. The single stage controller arrangement of the proposed CM-ICT offers easier compensation. Analysis, Matlab/Simulink simulations, and experimental results have been presented to validate the proposed technique.
\end{abstract}

Key Words: Current controller, Induction motor, Integrated control technique, Space vector modulation, Z-source inverter

\section{INTRODUCTION}

Since Z-source inverters (ZSI) overcome the limitations and problems associated with traditional voltage source inverters (VSI) and current source inverters (CSI), they have found wide spread applications and attracted the interest of researchers in recent years. ZSI based adjustable speed drive systems (ASD) advantageously utilize the shoot-through states to boost the dc bus voltage by gating on both the upper and lower switches of the same phase leg. Shoot-through mode allows simultaneous conduction of devices in the same phase leg. Therefore, a ZSI can boost or buck a voltage that is equal to a desired output voltage and is greater/less than the DC bus voltage based on the boost factor. Since the shoot-through state has no harmful effect on the inverter and is advantageously utilized, the reliability of the inverter is greatly improved [1]. It also provides a low cost and highly efficient single stage power conversion structure for reliable operation. The above features make ZSI fed ASD systems highly desirable and reliable when compared to VSI/CSI fed ASDs. Voltage sags can disrupt an ASD system and shut down the critical loads and processes. Most of the power quality related problems in ASDs are due to the short-lived (typically $0.1-2 \mathrm{~s}$ ) voltage dips or sags of $10-50 \%$ below the nominal voltage. The DC capacitor in an ASD cannot hold DC voltage above the operable level

\footnotetext{
Manuscript received Oct. 28, 2009; revised Apr. 7, 2010

$\dagger$ Corresponding Author: s_thangaprakash@ rediffmail.com

Tel: +91-9842659966, Sri Shakthi Institute of Eng. \& Tech.

${ }^{*}$ Dean, K.S.R. College of Engineering, India.
}

under such voltage sags because it is a relatively small energy storage element. It leads to a lack of ride-through capability for sensitive loads driven by ASDs.

Inverter bridges with an impedance source (Z-source) connected after the DC power supply with the feature of buckboost capability was first proposed by Peng [1]. In this paper, a simple boost control method with constant boost factor was used to control the shoot-through and output voltage of the inverter. Then maximum boost control was proposed to produce the maximum voltage gain (boost) under a given modulation index [2]. Shen, et al. proposed a constant boost control which can obtain the maximum voltage gain at any given modulation index without producing the low-frequency ripple related to the output frequency while minimizing the voltage stress [3]. A detailed analysis of how the various conventional pulse width modulation strategies can be modified to switch a ZSI either continuously or discontinuously, while retaining all the unique harmonic performance features is discussed by Loh, et al [4]. A ZSI based control for general purpose motor drive systems has been proposed by Peng, et al. and it outlined the features and advantages of ZSI fed induction motor systems over the traditional VSI/CSI based systems [5]. The development and a comprehensive model of a ZSI with multi-loop controllers has been discussed by Gajanayake, et al. [6], and the application of a ZSI for traction drives has been discussed by Peng, et al [7]. An indirect controller for the dc-link voltage on the dc side of a ZSI was given by Tran, et al [8]. Controller design for specific applications, namely fuel cell and voltage sag compensation 


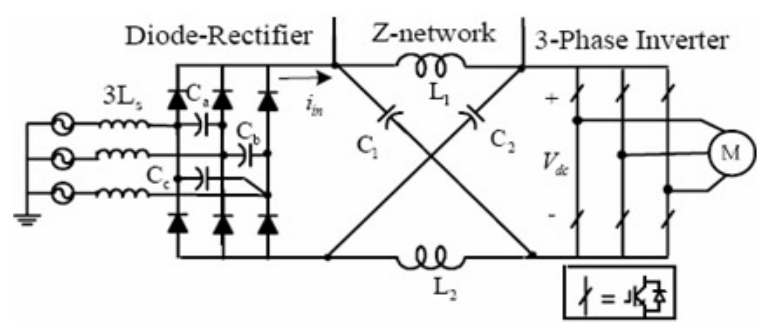

Fig. 1. Z-source inverter fed drive system.

are discussed by Jung, et al [9]. A unified control technique has been presented for ZSIs with a minimal number of sensors and PI controllers to achieve good stability for the overall system [10]. Modified voltage space vector modulation with an integrated control technique (ICT) has been proposed for the effective control of a ZSI with a single stage controller [11]. For the same operating points, this technique provides better control to the DC link voltage and AC output voltage. However this control technique is implemented only in the outer voltage controller loop and for RL loads. The transient modeling of a ZSI and analysis with small signal modeling and resonant damping in current mode operation has been reported by various authors [12]-[14]. The operating principle including the different modes of operation for a current mode ZSI fed induction motor drive system has been discussed by Fang, et al [15].

For ZSI fed induction motor drives, the stator current must be limited to the operable range. The presence of an inner current loop will improve the control characteristics of a drive with current limiting and is proposed in this paper. The results of simulations and experiments are given to validate the proposed control technique. In the next chapter, a brief discussion of ZSI fed motor drives is outlined followed by a review of MSVM with its salient features. The implementation of the proposed CM-ICT is discussed in chapter 4. Then the responses of the controllers and the performance of the ZSI fed motor drive system are analyzed.

\section{Z-SOURCE INVERTER FED INDUCTION MOTOR DRIVES}

Fig. 1 shows a schematic of a ZSI fed induction motor drive system. A ZSI fed induction motor drive system has four major parts: a diode rectifier, a Z-source (containing two series inductors and two equal, diagonally connected capacitors), an inverter bridge and a three phase induction motor load. Small values of input capacitors $\left(C_{a}, C_{b}\right.$ and $\left.C_{c}\right)$ are connected to the front end diode rectifier supply to serve as filter. These modifications in the power circuit arrangements can be easily adapted and implemented from traditional VSI/CSI fed induction motor drive systems. Since the ZSI bridge can boost the DC capacitors' $\left(C_{1}\right.$ and $\left.C_{2}\right)$ voltage to any value that is above the average DC value of the rectifier, a desired output voltage is always obtainable regardless of the line voltage. This section outlines the important expressions of a ZSI fed induction motor drive, its equivalent circuit, operating principle and traditional control methods which have been well established in recent years [5], [7].

Depending on how much a voltage boost is needed, the shoot-through interval $\left(T_{0} / 3\right)$ or its modulation index is de- termined. The peak dc-link voltage across the inverter bridge can be written as:

$$
V_{c 1}=V_{c 2}=\frac{1-\frac{T_{0}}{T}}{1-2 \frac{T_{0}}{T}} * V_{0}=\frac{1-D_{0}}{1-2 D_{0}} * V_{0}=\frac{B+1}{2} * V_{0}
$$

where $B=\frac{1}{1-2 D_{0}}$

$$
\begin{aligned}
& \hat{v}_{a c}=m_{a} * B * \frac{V_{0}}{2} \\
& V_{0}=\frac{3 \sqrt{2}}{\pi} * V_{L L}=1.35 * V_{L L}
\end{aligned}
$$

where $\mathrm{B}$ is the boost factor and $D_{0}$ is the shoot-through duty ratio. $V_{0}$ is the DC voltage of the rectifier fed from the line with a line-to-line rms value of $V_{L L}$. It should be noted that the equivalent DC voltage across the inverter bridge $\left(V_{d c}\right)$, is not the same to the dc capacitor voltages $\left(V_{c 1}\right.$ and $\left.V_{c 2}\right) . V_{d c}$ can be expressed as follows:

$$
V_{d c}=B * V_{0}=\frac{2 B}{B+1} * V_{0}
$$

During a supply voltage sag/dip, the boost mode of operation is enabled and the boost factor is maintained to be greater than one.

\section{Modified Voltage Space Vector}

Modified voltage space vector offers a better boost in the dc link voltage with an improved harmonic profile of the line parameters. The modulation signal produced by traditional space vector modulation (SVM) cannot produce a line voltage space vector beyond $\sqrt{3} / 2$. Under the boost mode of operation of a ZSI, the length of the line voltage space vector should be extendable to assure a wide range of controllability. Modified space vector modulation is reviewed in this section which allows the line voltage space vector to be operated beyond $\sqrt{3} / 2$. The shoot-through states boost the dc-link capacitor voltages and can partially supplement the null states within a fixed switching cycle without altering the normalized voltsec average. The continuous centered SVM state sequence of a conventional three-phase-leg VSI has three state transitions (e.g., null (000) $\rightarrow$ active $(100) \rightarrow$ active $(110) \rightarrow$ null (111)) and the null states at the start and end of a switching cycle $T_{s}$ span equal time intervals to achieve optimal harmonic performance. With three-state transitions, three equal-interval $\left(T_{0} / 3\right)$ shoot-through states can be added immediately adjacent to the active states in each switching cycle for modulating a ZSI where $T_{0}$ is the shoot-through time period in one switching cycle.

Normally the shoot-through duty ratio is defined as follows:

$$
D_{0}=\min \left(\frac{T_{z}}{T_{s}}\right) \quad ; \quad \text { for } \quad \theta=0 \rightarrow 2 \pi
$$

where $T_{z}$ is the traditional zero vector time period. Furthermore, $D_{0}$ can be related with the modulation index $\left(m_{a}\right)$ as:

$$
\begin{aligned}
& D_{0}=1-m_{a} \\
& B=\frac{1}{1-2 D_{0}}=\frac{1}{\frac{4}{\sqrt{3}}|V|-1} .
\end{aligned}
$$




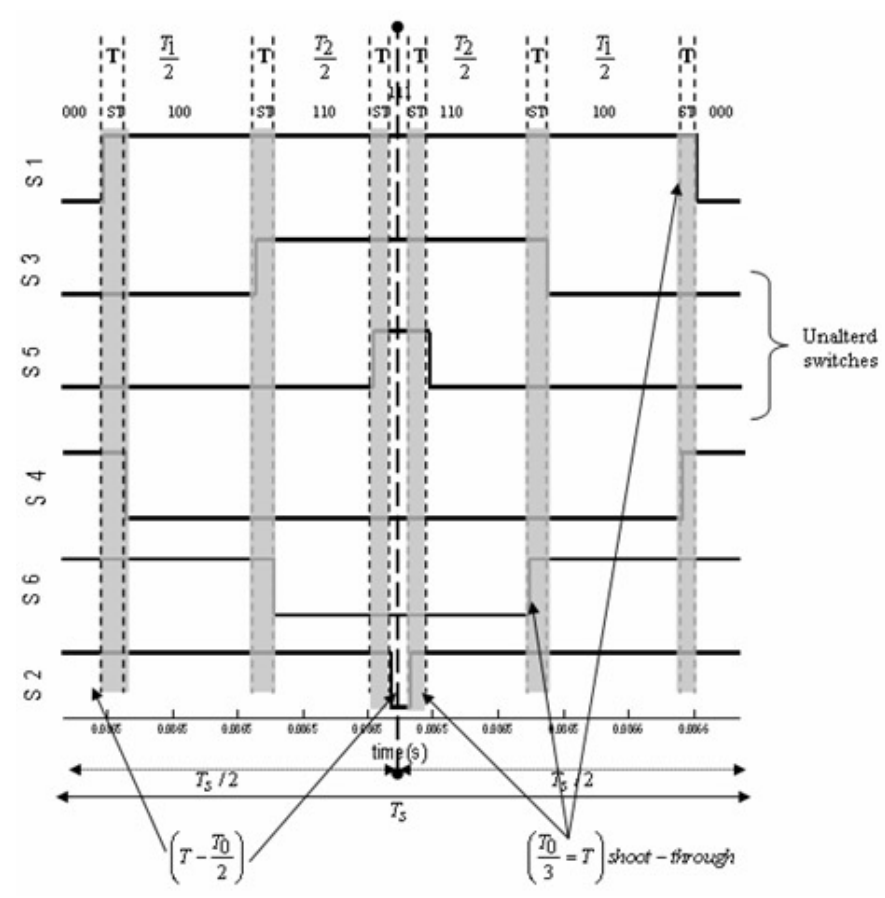

Fig. 2. Modified switching pulses.

Preferably, the shoot-through states should be inserted so that equal null intervals are again maintained at the start and end of the switching cycle to achieve the same optimal harmonic performance. The middle shoot-through state is symmetrically placed about the original switching instant. The active states $\{100\}$ and $\{110\}$ are left/right shifted accordingly by $\left(T_{0} / 3\right)$ with their time intervals kept constant. Then the remaining two shoot-through states are inserted within the null intervals, immediately adjacent to the left of the first state transition and to the right of the second transition. This way of sequencing inverter states also ensures a single device switching at all transitions.

The modulating signal for the MSVM strategy can be derived from the following equations:

$$
\begin{aligned}
& V_{\max }(s p)=V_{\max }+V_{o f f}+T \\
& V_{\max }(s n)=V_{\max }+V_{o f f} \\
& V_{\text {mid }}(s p)=V_{\text {mid }}+V_{o f f} \\
& V_{\text {mid }}(s n)=V_{\text {mid }}+V_{o f f}-T \\
& V_{\min }(s p)=V_{\text {min }}+V_{o f f}-T \\
& V_{\min }(s n)=V_{\min }+V_{o f f}-2 T \\
& \{s p, s n\}=\{1,4\},\{3,6\},\{5,2\}
\end{aligned}
$$

where $T=\left(T_{0} / 3\right)$ for the shoot-through duty ratio as well as the sp-positive and sn-negative group switches.

The maximum period of traditional zero vectors has been turned into a shoot-through state and it results in an effective DC voltage boost across the Z-source capacitors, because the inserted shoot-through interval period is $\left(T_{0} / 3\right)$, but with the traditional methods it is $\left(T_{0} / 6\right)$. In MSVM, only four switching waveforms, such as $S_{1}, S_{2}, S_{5}$, and $S_{6}$, out of six have been altered (either increased or reduced with the insertion of shoot-through). Two switches, such as $S_{3}$ and
$S_{4}$, remain unaltered and hence it offers the lowest switching stress when compared to traditional SVM methods, where all the six switches are altered. The switching pulse pattern of MSVM with shoot-through has been shown in Fig. 2. MSVM provides better dc link voltage boost by turning the maximum period of the traditional zero vectors into a shoot-through zero period. This results in lower switching stress to the power devices, less capacitor voltage/inductor current ripples and a better harmonic profile for the motor terminal voltage/current waveforms [11].

\section{Current Mode Integrated Control Technique}

\section{A. Integrated control technique}

Traditional induction motor drives are often disturbed by either supply voltage sags or fluctuations. These problems are not unusual in photovoltaic, wind power and fuel cell powered applications. During such conditions, the output voltage may not be enough to supply the required power to the motor particularly when over drive operation is desired. The output AC voltage of a ZSI is based on the DC link voltage or the voltage across the $\mathrm{Z}$-source capacitors. In traditional methods, the Z-source capacitor voltage and the output voltage/current are used as feedback to achieve optimum voltage control of the output voltage. The ICT provides efficient operation with a single stage controller [11].

The modulation index and the shoot-through duty ratio are continuously regulated with respect to the feedback voltage/current signals to track the pre-defined reference voltage. For the same modulation index and shoot-through, MSVM provides a greater boost in the dc-link voltage than SVM in addition to its single stage controller structure. A single stage controller processes only the terminal voltage feedback to generate the required length of the space vector and shootthrough duty ratio. It ensures better stability of the overall system. The new vector $\vec{V}^{\prime}$, which is accomplished by both the operating cases during voltage sag/fluctuation as well as the traditional mode can be defined as:

$$
\overrightarrow{V^{\prime}}=B * \vec{V} \text {. }
$$

When there are no supply voltage sags/fluctuations, the DC source provides a constant supply to the inverter and the motor drive experiences smooth operation. In this case the ZSI behaves as a traditional VSI and the length of the modified voltage vector $\left|\vec{V}^{\prime}\right|$, is equal to the traditional voltage vector $|\vec{V}|$ and the shoot-through time period is zero. The boost factor in this case is always equal to one and this mode can be considered as a non-boost mode of operation from the view point of ZSI operation.

When $B$ is equal to one, equation (14) can be:

$$
\overrightarrow{V^{\prime}}=\vec{V}
$$

The length of the voltage space vector and the shoot-through duty ratio in this case can be written as follows:

$$
\left|\vec{V}^{\prime}\right|=|\vec{V}| ; \quad D_{0}=0 .
$$

When the supply voltage experiences sags/fluctuations, the motor drive is subjected to ride-through problems. In order 


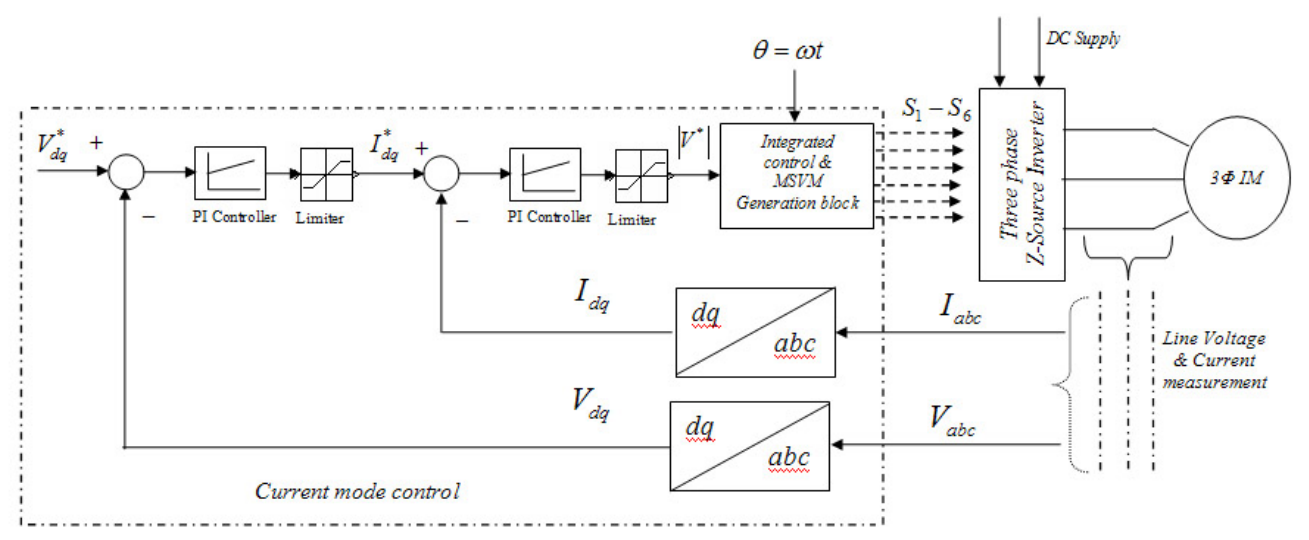

Fig. 3. Implementation block diagram of proposed CM-ICT.

to overcome this setback, the length of the modified voltage vector $\left|\vec{V}^{\prime}\right|$, should be extended beyond $(\sqrt{3} / 2)$. The shootthrough duty ratio is redefined as $D_{0}=\frac{2\left|V^{\prime}\right|}{4\left|V^{\prime}\right|-\sqrt{3}}$ to achieve better control performance. To boost the DC link voltage significantly during voltage sag, with equations (14) and (16), one can get the modified voltage vector as:

$$
\left|\vec{V}^{\prime}\right|=\frac{1}{\frac{4}{\sqrt{3}}\left|V^{\prime}\right|-1} *|\vec{V}| ; \quad D_{0}=\frac{2\left|V^{\prime}\right|}{4\left|V^{\prime}\right|-\sqrt{3}} .
$$

The output voltage vector can be boosted to the required level so that the Z-source capacitor voltage can be maintained as a constant throughout operation. During supply voltage fluctuations, the desired voltage can be supplied by the ZSI for the same modulation index and shoot-through duty ratio. Hence, the motor drives the load very smoothly even during load variations.

\section{B. Current mode control}

Fig. 3 shows the proposed CM-ICT with feedback control of the outer voltage loop and the inner current loop. The outer one controls the DC boost and output voltage of the ZSI and the inner one controls the line current to the motor terminals. The inner current feedback loop is proposed for the purpose of line current limiting and to produce a user defined current waveform. The outer voltage feedback loop, shown in Fig. 3, enforces the desired line voltage to the motor drive. The three phase line voltage variables $\left(V_{a b c}\right)$ are measured by the sensors and are transformed into the two phase variables $\left(V_{d q}\right)$ (or abcto-dq transformation). The magnitude of the dq component is then compared with the pre-defined reference voltage $\left(V^{*}{ }_{d q}\right)$.

The voltage error is processed through a PI controller and the resulting voltage command is limited and transformed into a stator current command $\left(I_{d q}{ }^{*}\right)$. For a zero voltage command, the currant command will not be a zero, but will be equal to the magnetizing current. The current command generated by the PI controller and limiter, is compared with the actual line current of the motor drive, and the error is processed through the PI controller and a limiter. This limiter ensures that, the control signal $\left|V^{*}\right|$ to the ZSI is constrained to a safe level. The

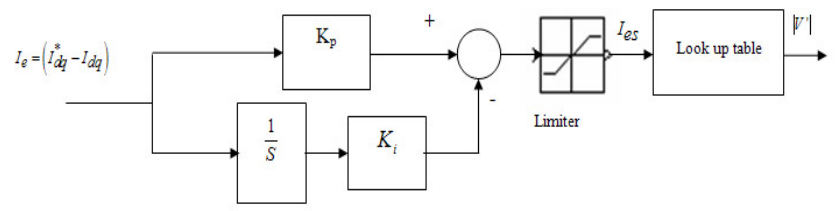

Fig. 4. Block diagram of inner PI current controller.

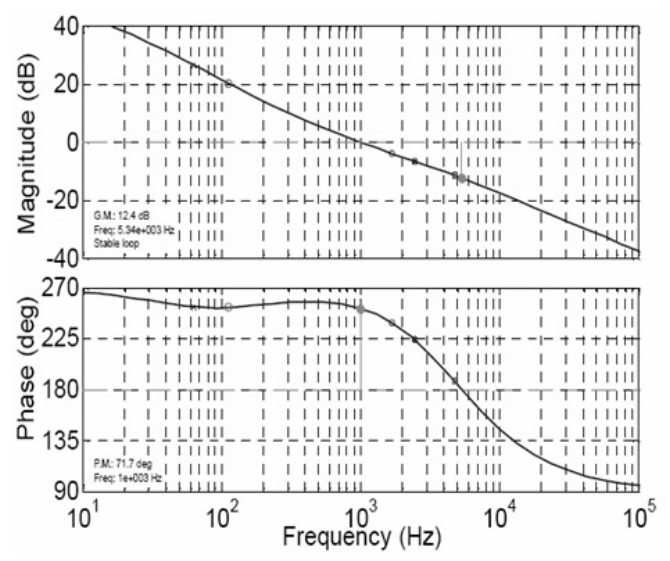

Fig. 5. Bode magnitude and phase plot of CM-ICT.

rises and falls of the control signal voltage are made gradual to protect the induction motor drive and ZSI from transients.

The required voltage space vector will be generated according to the value of the current control signal $I_{e s}$. The error of the current controller can be:

$$
I_{e}=I_{d q}^{*}-I_{d q} .
$$

The current controller arrangement with a compensator is shown in Fig. 4. The most common choice for a controller in ASDs is a PI controller due to its simple structure and satisfactory performance over a wide range of operating conditions. Since the derivative component of a PID controller introduces surplus noise during operation, the PI controllers found wide spread application in the control of electrical drives. To design and tune the PI controller gains, a number of frequency response methods such as the root locus and pole assignment design techniques, etc. have been proposed. All of these methods are considered to be model based 


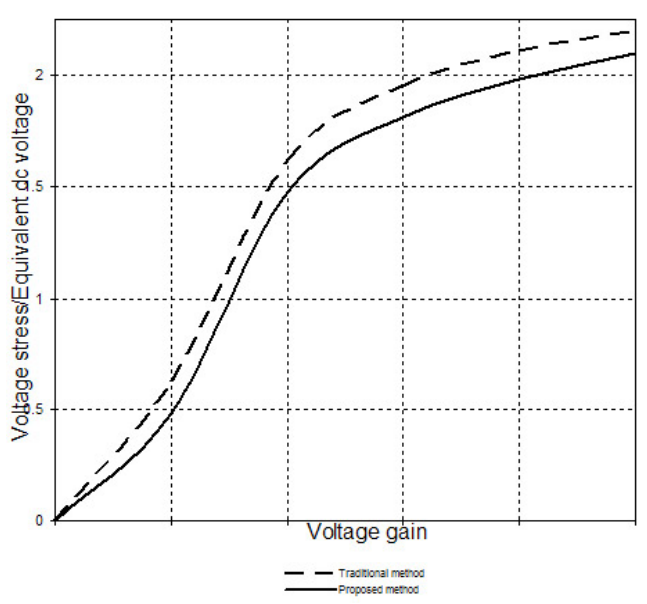

Fig. 6. Graph between voltage ratio stress versus voltage gain by traditional and proposed methods.
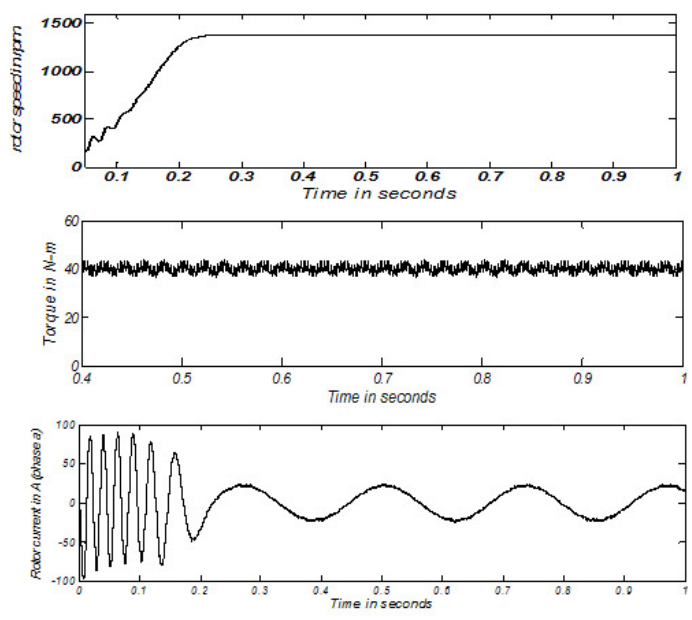

Fig. 7. Simulation results of CM-ICT for constant load.

strategies and so the efficiency of the tuning law depends on the accuracy of the proposed model as well as the assumed conditions with respect to the actual operating conditions. In this paper, the Ziegler-Nichols method has been used to tune the PI controllers since it does not require any system model and the control parameters are designed from the plant step response only [16]. Tuning, using the Ziegler-Nichols method is characterized by good disturbance rejection. The transfer function of a ZSI fed induction motor system is derived from its transient model [12]. The peak voltage of the sinusoidal control signal generated by a CM-ICT, is the modulation index and this is compared with the high frequency ramp signal to generate switching pulses to the gates of the IGBTs. The shoot-through time period computed by the ICT is inserted into the switching waveforms with the help of logical gates. Then the switching pulses with the shoot-through are sent to the gates of the power devices through the gate drive and isolation circuits.

Similar to the voltage feedback control method; the output variable to be controlled is the terminal voltage of the induction motor drive. The inner current loop should be fast enough to track the line current to the reference current, so

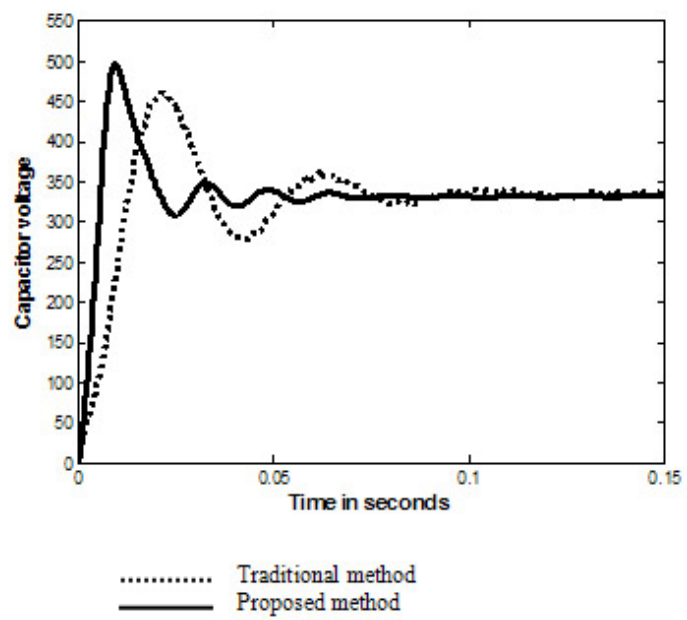

Fig. 8. Transient response of Z-source capacitor voltage by traditional SVM and Modified SVM.

that the current sensor gain, which behaves like a proportional controller, is enough for inner loop compensation. The frequency response of the bode magnitude and phase plots for the CM-ICT are shown in Fig. 5. It can be seen that, the gain margin and phase margin of the CM-ICT is positive with a significant value, thus it provides better stability to the overall system. Compared to the voltage feedback controlled case, it is observed that the compensation is easier in the ICT with an inner current controller. Fig. 6 shows the voltage ratio stresses of the traditional and the proposed methods. As can be seen in Fig. 6, the proposed method has a lower voltage stress ratio than the traditional method.

\section{RESUlTS AND DisCUSSION}

The traditional and proposed control techniques have been simulated by Matlab/Simulink software and the results are verified by experiment. The input parameters for the system elements for the Matlab/Simulink simulations are provided in Table I. The simulation is performed for a squirrel cage induction motor rated at $10 \mathrm{hp}(7.5 \mathrm{~kW}), 400-\mathrm{V}, 50 \mathrm{~Hz}$ and $1440 \mathrm{rpm}$. Simulation results are given for the different operating modes of the induction motor drive. Fig. 7 shows the simulation results of the rotor speed response, the torque response and the rotor current waveform when the induction motor is driving a constant load (40 N-m) with a constant DC supply.

TABLE I

SYSTEM PARAMETERS

\begin{tabular}{|c|c|}
\hline Parameter & Specification \\
\hline DC Supply & $300 \mathrm{~V}$ \\
\hline Output frequency & $50 \mathrm{~Hz}$ \\
\hline Switching frequency & $10 \mathrm{kHz}$ \\
\hline$C_{1}=C_{2}=C$ & $2200 \mu \mathrm{F}$ \\
\hline$L_{1}=L_{2}=L$ & $1 \mathrm{mH}$ \\
\hline
\end{tabular}

The transient behavior of Z-source capacitor voltage for the traditional mode and the CM-ICT, while maintaining 

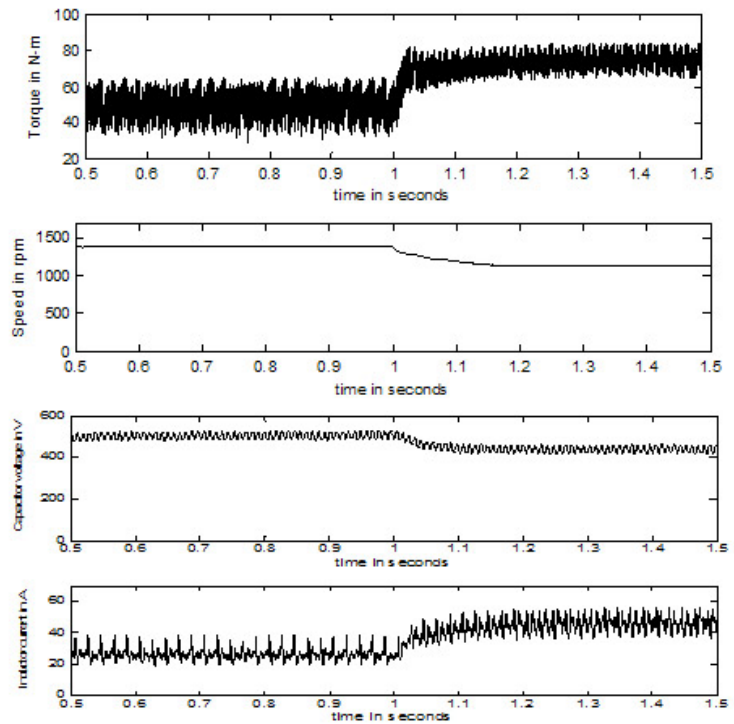

Fig. 9. Dynamic behavior under step change in load.

(a)
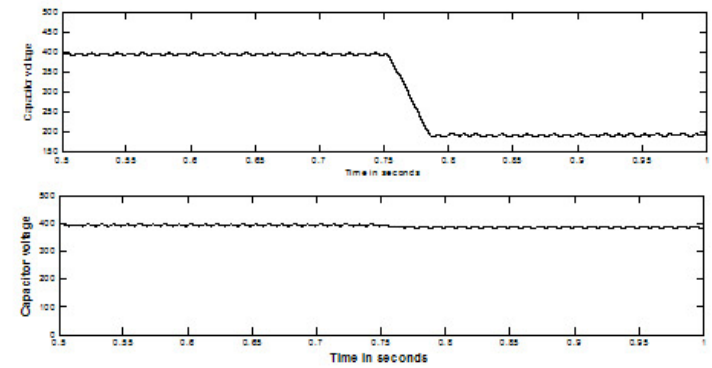

(b)

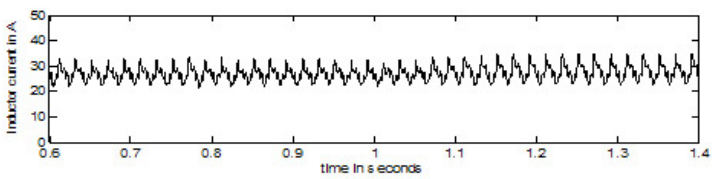

Fig. 10. Dynamic behavior of $\mathrm{Z}$ source capacitor voltage during $50 \%$ voltage sag (a). Traditional system (b) CM-ICT along with inductor current waveform.

$350 \mathrm{~V}$ across the capacitor is depicted in Fig. 8. The time response of the proposed system has a smoother transient behavior than the traditional method. MSVM provides better transient behavior for a Z-source capacitor voltage that is being regulated frequently. The dynamic behavior of the Zsource elements has been shown in Fig. 9, when a step change is applied to the load. It can be seen that, even after the application of a step change in the load, the response is very smooth over time. Fig. 9 also shows the simulation results of the torque response versus time and the speed response versus time for the proposed ZSI fed motor drive system with an applied load of $40 \mathrm{~N}-\mathrm{m}$. The Z-source capacitor voltage and inductor current when the DC supply voltage experiences a 50\% sag is shown in Fig. 10. The voltage across the Zsource capacitor is maintained almost constant in the proposed method when a sag appears and hence the drive is supplied by a constant voltage source throughout its operation.

The time harmonics present in the terminal voltage waveform (the output of ZSI) produce respective rotor harmonics, which in turn interact with the fundamental air-gap

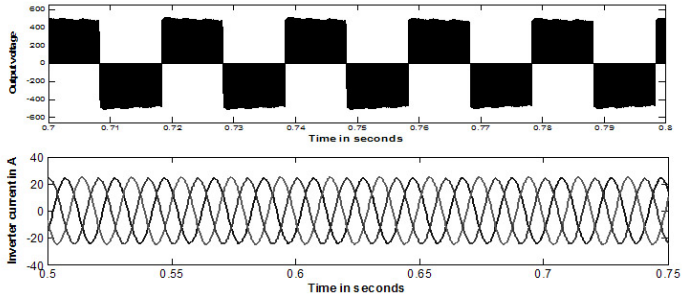

Fig. 11. Inverter output voltage and the output current waveforms under $50 \%$ supply voltage sag (CM-ICT).

flux, generating undesirable harmonic torque pulsations. They generate undesirable noise, speed pulsations and losses thus reducing the thermal capability of the motor and ultimately they result in a degrading of the motor. MSVM provides a better harmonics profile in the line parameters when compared to the traditional method. Table II shows a comparison of the line voltage/current harmonic profiles for different values of the shoot-through and for supply voltage sags generated intentionally through simulation. The proposed system has a better harmonic profile in almost all of the cases. The inverter output voltage and the output current waveforms under a $50 \%$ supply voltage sag by the CM-ICT is shown in Fig. 11.

The results shown in the simulation are verified by experiments in the laboratory. The control system is implemented with a DSP-type TMS320C6713 for voltage control and the MSVM scheme. The AC output voltage and current are sensed by isolation devices, amplifiers, and a 12-bit analog-to digital converter within the DSP. The PWM pulses generated by the DSP were then sent out through six independent PWM channels to gate the six switches (IGBT modules) of the implemented inverter. The hardware modulation signal and the high frequency triangular signal were generated by the DSP and then compared to generate the switching pulses to the inverter. The experimental switching line voltage and the current waveform of the inverter after the LC filter with a cutoff frequency of $1 \mathrm{kHz}$ for $m_{a}=0.85 ; D_{o}=0.2$; boost factor $\mathrm{B}=1.5$ for $300 V_{d c}$ for a switching frequency of $5 \mathrm{kHz}$ are shown in Fig. 12. Fig. 13 shows the voltage across the Zsource capacitor and the current through the Z-source inductor respectively, when a $25 \%$ sag is experienced. The voltage sag is intentionally applied at $1 \mathrm{~s}$. The Z-source capacitor voltage and the inductor current waveforms during a $25 \%$ supply voltage sag by the proposed CM-ICT has been improved well. The DC boost is found to be good for the same shootthrough duty ratio. The voltage across the Z-source capacitor is maintained constantly at the desired level during the supply voltage sag/fluctuations.

TABLE II

HARMONIC PROFILE

\begin{tabular}{|c|c|c|c|c|c|}
\hline \multirow{2}{*}{ Method } & \multirow{2}{*}{ Do } & \multicolumn{2}{|c|}{$10 \%$ voltage sag } & \multicolumn{2}{c|}{$40 \%$ voltage sag } \\
\cline { 3 - 6 } & & $T H D_{v} \%$ & $T H D_{i} \%$ & $T H D_{v} \%$ & $T H D_{i} \%$ \\
\hline \multirow{2}{*}{ SVM } & 0.2 & 13.8 & 2.18 & 14.2 & 2.5 \\
\cline { 2 - 6 } & 0.3 & 15.2 & 2.5 & 16.1 & 2.6 \\
\hline \multirow{2}{*}{ MSVM } & 0.2 & 9.5 & 1.8 & 10.1 & 0.5 \\
\cline { 2 - 6 } & 0.3 & 11.3 & 1.6 & 12.4 & 0.8 \\
\hline
\end{tabular}



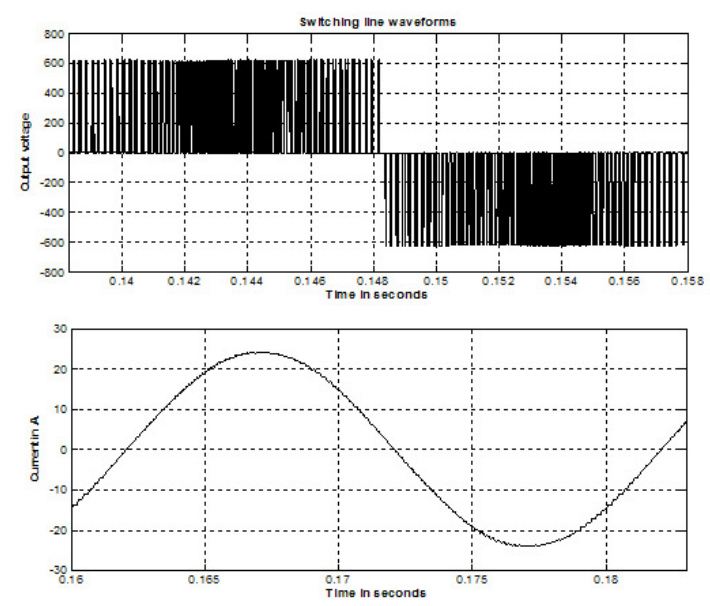

Fig. 12. Switching line voltage and line current wave form (experimental).
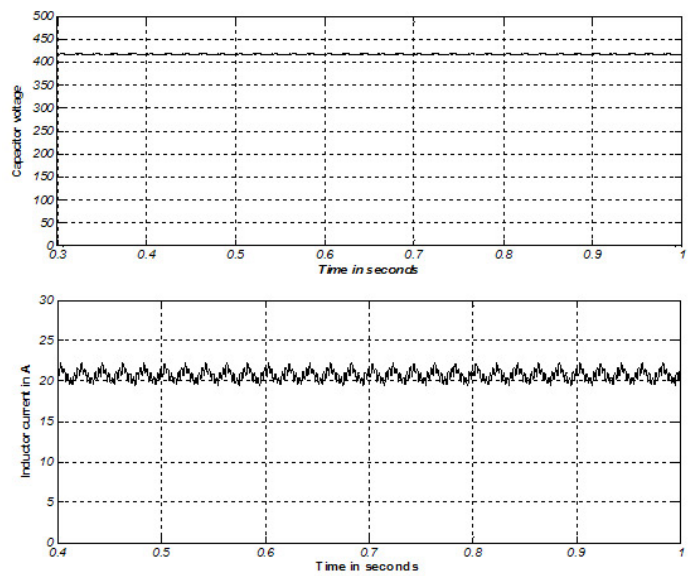

Fig. 13. Voltage across Z-source capacitor and current through Z-source inductor during $25 \%$ sag (experimental).

The shoot-through duty ratio is increased to improve the dc-link voltage. There is no significant change in the Z-source inductor current waveform.

\section{Vi. CONCLUSions}

A current mode integrated control technique with a modified voltage space vector for ZSI fed motor drives has been proposed in this paper. MSVM provides a better DC link voltage boost with a superior harmonic profile in the $\mathrm{AC}$ output waveform for the same shoot-through duty ratio and modulation index. The inner current loop provides better line current limitation to the drive and protects it from overcurrent disruptions. The modulation index and shoot-through are regulated continuously to track the reference voltage. The proposed CM-ICT has better stability than traditional methods and it has been verified by frequency response plots. Compared to the VM-ICT, it is observed that compensation is easier with the CM-ICT. The performance of an induction motor drive with the CM-ICT in all operating environments is also found to be smooth. Simulation and experimentation have been performed for different operating conditions of the drive and the results are given.

\section{REFERENCES}

[1] F. Z. Peng, "Z-source inverter," IEEE Transactions on Industry Applications, Vol. 39, No. 2, pp.504-510, Mar. 2003.

[2] F. Z. Peng, M. Shen and Z. Qian, "Maximum boost control of the Zsource inverter," IEEE Transactions on Power Electronics, Vol. 20, No. 4, pp. 833-838, Jul. 2005.

[3] M. Shen, J. Wang, A. Joseph, F. Z. Peng, L. M. Tolbert and D. J. Adams, "Constant boost control of the Z-source inverter to minimize current ripple and voltage stress," IEEE Transactions on Industry Applications, Vol. 42, No. 3, pp. 770-778, May 2006.

[4] P. C. Loh, M. Vilathgamuwa, Y. S. Lai, G. T. Chua and Y. W. Li, "Pulse width modulation of Z-source inverters," IEEE Transactions on Power Electronics, Vol. 20, No. 6, pp.1346-1355, Nov. 2005.

[5] F. Z. Peng, X. Yuvan, X. Fang and Z. Qian, "Z-source inverter for motor drives," IEEE Transactions on Power Electronics, Vol. 20, No. 4, pp.857-863, Jul. 2005.

[6] C. J. Gajanayake, M. Vilathgamuwa and P. C. Loh, "Development of a comprehensive model and a multi-loop controller for Z-source inverter DG system," IEEE Transactions on Industrial Electronics, Vol. 54, No. 4, pp. 2352-2359, Aug. 2007.

[7] F. Z. Peng, M. Shen and K. Holland, "Application of Z-source inverter for traction drive of fuel cell-battery hybrid electric vehicles," IEEE Transactions on Power Electronics, Vol. 22, No. 3, pp.1054-1061, May 2007.

[8] Q. V. Tran, T. W. Chun, J. R. Ahn and H. H. Lee, "Algorithms for controlling both the DC boost and AC output voltage of Z-source inverter," IEEE Transactions on Industrial Electronics, Vol. 54, No. 5, pp. 2745-2750, Oct. 2007

[9] J. W. Jung and A. Keyhani, "Control of a fuel cell based Z-source converter," IEEE Transactions on Energy Conversion, Vol. 22, No. 2, pp. 467-476, Jun. 2007.

[10] S. Yang, X. Ding, F. Z. Peng, and F. Z. Z. Qian, "Unified control technique for Z-source inverter," Proceedings. IEEE - PESC 2008, pp. 3236 - 3242, Jun. 2008.

[11] S. Thangaprakash and A. Krishnan, "Integrated control algorithm for an effective control of Z-source inverter using modified voltage space vector," Australian Journal of Electrical and Electronics Engineering, Vol. 7, No. 1, pp. 53-64, Feb. 2010.

[12] P. C. Loh, D. M. Vilathgamuwa, C. J Gajanayake, Y. R. Lim, and C. W. Teo, "Transient modeling and analysis of pulse width modulated Zsource inverter," IEEE Transactions on Power Electronics, Vol. 22, No. 2, pp. 498-507, Mar. 2007.

[13] J. Liu, J. Hu, and L. Xu, "Dynamic modeling and analysis of Z-source converter - derivation of AC small signal model and design-oriented analysis," IEEE Transactions on Power Electronics, Vol. 22, No. 5, pp. 1786-1796, Sep. 2007.

[14] P. C. Loh, C. J. Gajanayake, D. M. Vilathgamuwa, and F. Blaabjerg, "Evaluation of resonant damping techniques for Z-source current-type inverter," IEEE Transactions on Power Electronics, Vol. 23, No. 4, pp. 2035-2043, Jul. 2008.

[15] X. Fang, Z. Qian, Q. Gao, B. Gu, F. Z. Peng, and X. Yuan, "Current mode Z-source inverter-fed ASD system," in Proc. of IEEE Power Electronics Specialists Conference, pp. 2805-2809, Jun. 2004.

[16] A. S. Elwer, "A novel technique for tuning PI controllers in induction motor drive system for electric vehicle applications," Journal of Power Electronics, Vol. 6, No. 4, pp. 322-329, Oct. 2006.

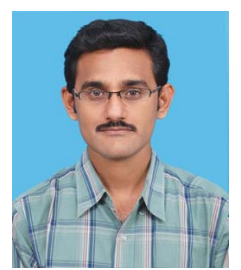

Sengodan Thangaprakash received his Bachelor of Engineering in Electrical and Electronics Engineering from Kongu Engineering College, Bharathiar University, Tamil Nadu, India in 2002 and his Master of Engineering in Power Electronics and Drives from the Government College of Technology, Tamilnadu, India in 2004. $\mathrm{He}$ is with the Department of Electrical and Electronics Engineering in the Sri Shakthi Institute of Engineering and Technology, Coimbatore, India. Currently he is working towards his $\mathrm{PhD}$ at Anna University, Chennai, India. His research interests include power electronics circuits, renewable power conversion systems and solid state control of electrical drives. He has published more than ten papers in international journals and conferences. 


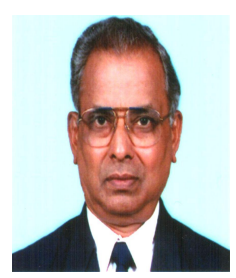

Ammasai Krishnan received his Bachelor of Engineering in Electrical Engineering and his Master of Engineering in Control Systems from Madras University, India in 1966 and 1974 respectively. Then he received his $\mathrm{PhD}$ in Electrical Engineering (Control \& Computers group) from the Indian Institute of Technology, Kanpur in 1979. He has been in the field of technical teaching and research for more than four decades at the Government College of Technology and the Coimbatore
Institute of Technology, Coimbatore, India. From 1994 to 1997, he was an Associate Professor in Electrical Engineering at the University Pertanian Malaysia (UPM), Malaysia. Currently he is a Dean of the K.S.R. College of Engineering, Tamil Nadu, India. His research interests include control systems, power electronics and electrical machines. He has published more than 180 papers in international journals and conferences. He is a senior member of IEEE. 